Acta vet. scand. $1977,18,384-396$.

From the National Veterinary Institute, Oslo, and the Department of Pathology, Veterinary College of Norway, Oslo.

\title{
INFLUENCE OF DIET ON EXPERIMENTAL SWINE DYSENTERY
}

\section{EFFECTS OF A VITAMIN E AND SELENIUM DEFICIENT DIET SUPPLEMENTED WITH $6.8 \%$ COD LIVER OIL}

\author{
By \\ Jon Teige jr., Knut Nordstoga \& Johan Aursjф
}

TEIGE, JON jr., KNUT NORDSTOGA \& JOHAN AURSJ $\emptyset:$ Influence of diet on experimental swine dysentery. 1. Effects of a vitamin $E$ and selenium deficient diet supplemented with $6.8 \%$ cod liver oil. Acta vet. scand. 1977, 18, 384-396. - Sixteen growing pigs were fed a vitamin $E$ and selenium deficient diet; half of the animals (Group 2) were given a daily supply of vitamin $E$ and selenium. After having been fed these diets for 53 days, the pigs were infected orally with minced colonic material from cases with typical swine dysentery. This exposure resulted in outbreaks of swine dysentery in both groups. The incubation times were, however, distinctly shorter and the clinical symptoms much more pronounced in Group 1 than in Group 2. The patho-morphological lesions in the colon also differed between the 2 groups. In the pigs of Group 1 evident pseudomembraneous lesions were observed in the spiral colon. In Group 2, the colonic alterations consisted predominantly of a catarrhal enteritis; pseudomembranes occurred in a minor part of colon in only 4 pigs. Both the clinical and the chemical observations and the pathological findings indicated a much better vitamin $E$ and selenium balance in the pigs of Group 2. It is concluded that the treatment with vitamin $E$ and selenium in Group 2 greatly increased resistance to swine dysentery.

swine dysentery; pseudomembraneous colitis; Treponema hyodysenteriae; vitamin E and selenium deficiency; diet.

Swine dysentery was originally reported by Whiting et al. in 1921. The disease was induced after inoculation with Vibrio coli (Doyle et al. 1944); however, the disease inductive with this organism has since proved difficult to repeat. Since 1970 a large spirochaete, Treponema hyodysenteriae, has been isolated from cases of swine dysentery (Harris 1974). The disease has, in recent years, been induced by inoculation with this microbe, often 
administered in colonic material from diseased pigs (Olson 1974). Thus $T$. hyodysenteriae is now recognized by many workers as the primary cause of swine dysentery. Several authors have, however, pointed out that both environmental and dietary factors may play a role in this enteric disease (Nordstoga et al. 1968, Eriksen \& Andersen 1970, Glock 1972).

It has been shown that pigs fed a diet deficient in vitamin $\mathbf{E}$ were susceptible to an experimental generalized Shwartzman reaction (Teige et al. 1973). It has also been suggested that the colonic lesions in swine dysentery may be the result of a local Shwartzman reaction (Nordstoga et al., Nordstoga 1973, Espinasse 1973), and that one possible factor could be a deficiency of vitamin $\mathbf{E}$ (Nordstoga).

In a preliminary experiment, 2 groups of pigs were inoculated with minced colon from cases with swine dysentery, and in a group fed a vitamin $\mathbf{E}$ deficient diet the inoculation resulted in diarrhoea and reduced appetite, whereas pigs in the other group, which were given vitamin $E$ supplementation, did not show any clinical signs (unpublished observations). The present report presents the results of an experiment in which 2 groups of pigs were inoculated with minced colon from pigs with swine dysentery. Both groups were fed a diet deficient in both vitamin $\mathbf{E}$ and selenium and supplemented with cod liver oil, in order to enhance the requirement for these 2 factors. Half of the animals (Group 2) were given a daily supply of vitamin $\mathbf{E}$ and selenium.

\section{Experimental animals}

\section{MATERIALS AND METHODS}

Sixteen pigs with an average weight of $16 \mathrm{~kg}(13-18.5 \mathrm{~kg})$ were used; the pigs were randomly divided into 2 equal groups (Groups 1 and 2) and given consecutive numbers (Nos. 1-16). All animals came from a herd with no history of outbreaks of swine dysentery. Except for 1 pig which had a transient diarrhoea for a few days on arrival at the experimental station, the pigs had no signs of intestinal disorders during the feeding period and also seemed to be in good health. The experiment was conducted in closed buildings. The pigs were kept in a pen with arrangements for individual feeding, and were handfed twice daily, given an adequate water supply and weighed individually every 2 weeks. The average weight gain per day during the feeding period was 410 and $460 \mathrm{~g}$ in Groups 1 and 2, respectively. 


\section{Experimental diet}

The basic ration given to the pigs of Group 1 had the following composition:

Toprina $^{\star} 15 \%$, barley $69 \%$, oats $13 \%$, and minerals ${ }^{\star \star}$ and vitamins $^{\star \star \star} 3 \%$. The basic ration had the following calculated contents per $\mathrm{kg}$ : calcium $7.5 \mathrm{~g}$, phosphorus $6.5 \mathrm{~g}$, lysine $9.1 \mathrm{~g}$, methionine and cystine $5.9 \mathrm{~g}$, and digestible raw protein $133 \mathrm{~g}$. In addition $6.8 \%$ cod liver oil $\dagger$ was incorporated into the basic ration. This oil was subjected to a silica earth absorption treatment as this procedure is supported to reduce the vitamin $\mathbf{E}$ content. After this treatment the oil contained $130 \mathrm{mg} \alpha$-tocopherol per kg. Samples of the basic ration without cod liver oil collected at the beginning of the feeding period contained $14 \mathrm{mg}$ $\alpha$-tocopherol $\dagger \dagger$ per $\mathrm{kg}$ and 0.0065 p.p.m. selenium $\dagger \dagger \dagger$. In a sample of the same feed collected at the end of the experiment no measurable amounts of $\alpha$-tocopherol were detected $\dagger \dagger$.

The cod liver oil was added to the feed at each feeding. The pigs in Group 2 received the same diet as in Group 1 but, in addition, a daily supply of $200 \mathrm{mg} \alpha$-tocopherol and $0.1 \mathrm{mg}$ selenium, given as sodium biselenite. At the time of inoculation the pigs had been fed the experimental diets for 53 days.

\section{Laboratory tests}

Blood samples were taken from the anterior vena cava at 1 , $3,5,7$ and 8 weeks after the beginning of the feeding period. The following determinations were performed: The values of haematocrit and haemoglobin, and the serum concentrations of

* Produced by British Petroleum.

* * The following were added in $\mathrm{g}$ per $100 \mathrm{~kg}$ feed: Dicalcium phosphate 700 , calcium carbonate 1350 , sodium chloride 250 , potassium chloride 400, magnesium carbonate 200 , ferrous sulphate 60 , manganese sulphate 10 , copper sulphate 4 , cobalt chloride 2 , zinc oxide 8 .

$\star \star \star$ The following were added in $\mathrm{mg}$ per $100 \mathrm{~kg}$ feed: Ascorbic acid 500, nicotinic acid 1600, calcium pantothenate 1100 , inositol 400 , choline chloride 35,000 , riboflavin 200 , biotin 20 , folic acid 70 , pyridoxine chloride 130 , thiamine hydrochloride 200 , vitamin $B_{12} 1 ; 200,000$ i. u. vitamin $A$ and 20,000 i. u. vitamin $D$ were also added per $100 \mathrm{~kg}$ feed.

$\dagger$ Produced by J. C. Martens and Co. Ltd., Bergen, Norway.

t† Analyses performed by Vitamininstituttet, Bergen, Norway.

$\dagger \dagger \dagger$ Analyses performed by Institutt for Atomenergi, Kjeller, Norway. 
glutamate-oxalacetate transaminase (GOT) * glutamate-pyruvate transaminase $(\mathrm{GPT}){ }^{\star}$ and lactate dehydrogenase $(\mathrm{LDH})^{*}$. In the last blood sample the plasma $\alpha$-tocopherol content ${ }^{\star \star}$ was also determined.

\section{Inoculation}

The inoculum consisted of colon and caecum from 3 pigs from a herd with persistent swine dysentery. In the 3 pigs, the pathological lesions were in accordance with the picture usually observed in swine dysentery (Harris \& Glock 1972). By phasecontrast microscopy the large spirochaetes could be seen in relatively large numbers in colonic samples. Bacteriological examinations of the same samples revealed no growth of Salmonella spp.

The intestinal material from the 3 pigs had been stored at $-20^{\circ} \mathrm{C}$ for 2,3 and 17 days, respectively, when it was thawed, minced, mixed together and divided into equal portions for each pig. Feed and water had been withheld from the pigs for approx. 20 hrs. when this inoculum was mixed with some feed and water in the crib; 3 hrs. later all the pigs had eaten the mixture.

\section{Clinical procedures}

Both before and after the inoculation the faecal appearance was observed and scored as shown in Table 3. Post inoculation (p.i.), at least 2 observations on faecal appearance were made each day. The daily food intakes and the incubation times are given in Tables 2 and 3, respectively. Faecal samples were collected $a$ ) before inoculation, $b$ ) between inoculation and the onset of diarrhoea and $c$ ) when diarrhoea appeared. Giemsa's staining was used on smears from specimens collected at time $a$, while specimens collected at time $b$ and $c$ were examined by phasecontrast microscopy.

\section{Killing}

Except for 2 pigs, No. 6 which died and No. 16 which was sent to a slaughter-house, all the animals were killed $72 \mathrm{hrs}$.

* Analytical procedures were according to Sigma Technical Bulletins (STB), for GOT and GPT: STB No. 505, 1964, Sigma Frankel (S-F) units, and for LDH: STB No. 500, 1960, Berger-Broida (B-B) units.

** Analytical procedure according to a method described by Hashim \& Schuttringer (1966). 
after they developed diarrhoea, with an intravenous injection of pentobarbital. Details of the necropsy procedures will be given in a subsequent paper. Liver samples were frozen and later analyzed for selenium ${ }^{\star}$.

\section{Microbiological procedures}

The pseudomembranes in colonic samples were removed, homogenized and diluted in saline 1:5. Mucosal scrapings from pigs without pseudomembranes were treated similarly. The suspension of mucosal material was centrifuged at low speed for 5 min. and samples from the supernatant examined by phasecontrast microscopy. Dilutions to 1:200 were prepared, and from each dilution inoculation was made onto $5 \%$ blood agar plates, which were incubated anaerobically in Gas Pak jars (BBL) at $37^{\circ} \mathrm{C}$ for 4 days. Routine bacteriological examinations, including analyses for salmonella, were also performed.

\section{Clinical-chemical findings ${ }^{\star \star}$}

RESULTS

Five weeks after the start of the feeding period the first elevation of the serum enzyme values was recorded for pig No. 6 which developed a GOT value of 121 . Two weeks later the following pigs in Group 1 showed elevations in some of the serum enzyme values: No. $1: \mathrm{LDH}=11,500, \mathrm{GOT}=260$ and $\mathrm{GPT}=205$, No. 3: GOT $=181$, No. 6: $\mathrm{LDH}=6900$, GOT $=257$ and GPT $=$ 144, and No. 8: GOT $=224$. In Group 2, 1 single pig, No. 9, showed the following elevation: GOT $=86$. The remaining animals all had normal values. The results of the next blood sampling ( 2 days p.i.) are recorded in Table 1 , together with the plasma $\alpha$-tocopherol determinations ${ }^{\star \star \star}$.

\section{Clinical findings after inoculation}

Observations on the feed consumption for the first 10 days p.i. are given in Table 2. The pigs surviving beyond this period ate their daily ration.

* Analytical procedures according to a fluorometric method described by Ihnat (1974).

* The serum enzyme tests were performed at the Research Station, Kjeller, Norway.

$\star \star \star$ Analyses performed by research fellow J. U. Skaare, the Veterinary College of Norway, Oslo. 
T a ble 1. Concentrations of serum enzymes and values of haematocrit, haemoglobin and plasma $\alpha$-tocopherol 2 days after the inoculation.

\begin{tabular}{|c|c|c|c|c|c|c|c|}
\hline Group & Pig No. & $\begin{array}{c}\text { LDH } \\
\text { (B-B units) }\end{array}$ & $\begin{array}{c}\text { GPT } \\
\text { (S-F units) }\end{array}$ & $\begin{array}{c}\text { GOT } \\
\text { (S-F units) }\end{array}$ & $\begin{array}{c}\text { Haematocrit } \\
(\%)\end{array}$ & $\begin{array}{l}\text { Haemoglobin } \\
(\mathrm{g} / \mathbf{1 0 0} \mathrm{ml})\end{array}$ & $\begin{array}{c}\text { Plasma } \alpha- \\
\text { tocopherol } \\
(\mu \mathrm{g} / \mathrm{ml})\end{array}$ \\
\hline \multirow{9}{*}{1} & 1 & 9900 & 235 & 138 & 34 & 11.9 & - \\
\hline & 2 & 1730 & 52 & 39 & 37 & 11.2 & 1.60 \\
\hline & 3 & 2200 & 60 & 70 & 32 & 9.3 & 0.40 \\
\hline & 4 & 1830 & 35 & 26 & 36 & 10.5 & 0.75 \\
\hline & 5 & 5800 & 62 & 48 & 34 & 10.5 & 1.60 \\
\hline & 6 & 6500 & 200 & 250 & 36 & 10.8 & 1.35 \\
\hline & 7 & 1550 & 44 & 42 & 43 & 11.9 & 1.35 \\
\hline & 8 & 2700 & 84 & 99 & 30 & 9.0 & 1.05 \\
\hline & mean $\pm s$ & $4026 \pm 3049$ & $97 \pm 76.6$ & $89 \pm 76.8$ & $835 \pm 3.9$ & $10.6 \pm 1.1$ & $1.16^{\star} \pm 0.45$ \\
\hline \multirow{9}{*}{2} & 9 & 3250 & 46 & 41 & 36 & 10.1 & - \\
\hline & 10 & 1510 & 44 & 67 & 36 & 10.5 & 1.90 \\
\hline & 11 & 2500 & 61 & 68 & 40 & 11.6 & 1.90 \\
\hline & 12 & 2500 & 46 & 36 & 35 & 9.8 & 2.30 \\
\hline & 13 & 1780 & 42 & 31 & 35 & 10.7 & 3.25 \\
\hline & 14 & 1400 & 61 & 44 & 40 & 11.0 & 2.90 \\
\hline & 15 & 1380 & 46 & 24 & 32 & 9.9 & 1.35 \\
\hline & 16 & 2050 & 50 & 40 & 34 & 10.1 & 1.90 \\
\hline & mean $\pm s$ & $2046 \pm 663$ & $50 \pm 7.4$ & $44 \pm 15.9$ & $936 \pm 2.8$ & $10.5 \pm 0.6$ & $2.21 \pm 0.66$ \\
\hline
\end{tabular}

* Statistically different from group 2 (P@0.01).

The mean incubation time for the pigs in Group 1 was 8.5 days and 13.4 days in Group 2 for the 7 pigs developing diarrhoea (Table 3) (statistically different, $\mathrm{P} \leqq 0.01$ ). The last pig (No. 16 ) in the group was killed 25 days p.i. as mo symptoms indicating swine dysentery had been observed. In 5 of the pigs in Group 1 the stools had a watery and bloody character (Table 3). The

T a b l e 2. Daily feed consumption after the inoculation. The figures refer to the number of pigs not eating their feed the day after inoculation. The figure 1 recorded from day 6 to 9 in Group 2 refers to pig No. 9.

\begin{tabular}{lllllllllll}
\hline $\begin{array}{l}\text { Days after } \\
\text { inoculation }\end{array}$ & 1 & 2 & 3 & 4 & 5 & 6 & 7 & 8 & 9 & 10 \\
\hline Group 1 & 0 & 0 & 3 & 2 & 3 & 2 & 3 & 1 & 5 & 7 \\
Group 2 & 0 & 0 & 4 & 0 & 0 & 1 & 1 & 1 & 1 & 0 \\
\hline
\end{tabular}


enteric disorder seemed, according to the appearance of the excrements, to get worse during the 72 hrs. of observation; pigs Nos. 1 to 6 had a gaunt appearance also. In Group 2 the pigs had, with a single exception (No. 13), either entirely normal or soft faeces on the day of killing; in most of the same pigs the faecal appearance seemed gradually to become normal, and the pigs were otherwise in good health. All the pigs suffered from a sarcoptic infestation which caused only a moderate itching during the feeding period; this itching became more pronounced for a couple of days when the first signs of diarrhoea appeared. Phasecontrast microscopy of faeces collected 3 days p.i. revealed no spirochaetes, but 2 days later large spirochaetes were detected in faecal samples, and after the onset of diarrhoea, large spirochaetes were consistantly found by phase-contrast microscopy.

\section{Pathological findings}

A survey of the macroscopical lesions in colon is given in Table 3, together with the occurrence of lesions attributed to vitamin $\mathrm{E}$ and selenium deficiency, i.e. yellow fat disease, hepatosis dietetica, skeletal muscle degeneration and myocardial degeneration. A detailed description of the pathological findings will be published in a subsequent paper.

\section{Liver selenium}

The content of selenium in the livers is recorded in Table $3^{\star}$.

\section{Microbiological findings}

Phase-contrast microscopy of the suspension from the colonic mucosa revealed numerous large spirochaetes in all the pigs of Group 1; spirochaetes were also recovered from 5 of these pigs (Nos. 1, 2, 3, 4 and 6), by cultivation. These organisms showed morphology, motility and growth characteristics which were in accordance with the description of $\mathrm{T}$. hyodysenteriae (Harris et al. 1972). In Group 2, large spirochaetes were found by phasecontrast microscopy in 7 of the pigs. (Nos. 9 to 15); the number of spirochaetes, however, was moderate in these animals and by

* Analyses performed at the Department of Toxicology, National Veterinary Institute, Oslo. 
T a b le 3. Weights of the pigs, clinical observations, necropsy findings and liver selenium values.

\begin{tabular}{|c|c|c|c|c|c|c|c|c|c|c|}
\hline \multirow{2}{*}{ Group } & \multirow{2}{*}{$\begin{array}{l}\text { Pig } \\
\text { No. }\end{array}$} & \multirow{2}{*}{$\begin{array}{c}\text { Weight }^{1} \\
\text { (kg) }\end{array}$} & \multirow{2}{*}{$\begin{array}{c}\text { Incu- } \\
\text { bation } \\
\text { period } \\
\text { (days) }\end{array}$} & \multicolumn{4}{|c|}{ Faecal appearance $^{2}$} & \multirow{2}{*}{$\begin{array}{l}\text { Lesions in } \\
\text { the spiral } \\
\text { colon }^{3}\end{array}$} & \multirow{2}{*}{$\begin{array}{l}\text { Lesions indicating } \\
\text { vit. E/selenium } \\
\text { deficiency }\end{array}$} & \multirow{2}{*}{$\begin{array}{c}\text { Liver } \\
\text { selenium } \\
(\mu \mathrm{g} / \mathrm{g})\end{array}$} \\
\hline & & & & 1 & 2 & 3 & 4 & & & \\
\hline \multirow{9}{*}{1} & 1 & 49 & 7 & H & $+t$ & H & t† & $\star \star \star \star \star \star$ & YF, $\quad-, \mathrm{MD}, \mathrm{HD}$. & 0.03 \\
\hline & 2 & 46 & 7 & H & $\dagger$ & tit & $H$ & $\star \star \star \star \star \star *$ & YF, SMD, - - - & 0.02 \\
\hline & 3 & 48 & 7 & $\dagger$ & H & $+\dagger$ & H† & 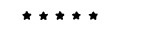 & YF, SMD, MD, 一. & 0.02 \\
\hline & 4 & 44 & 8 & $\dagger$ & H & + & H+ & $\star \star \star \star$ & $\mathrm{YF}, \quad-, \mathrm{MD},-$. & 0.02 \\
\hline & 5 & 46 & 8 & $+\dagger$ & +† & $+H^{2}$ & tit & $\star \star \star \star \star \star$ & YF, SMD, MD, - & 0.02 \\
\hline & 6 & 41 & 8 & t† & + & $+t^{+}$ & $\mathrm{D}^{5}$ & 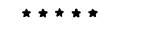 & YF, SMD, MD, HD. & $\bar{\Sigma} 0.02$ \\
\hline & 7 & 37 & 11 & $\dagger$ & $\dagger$ & $\dagger$ & $\dagger$ & $\star \star \star *$ & YF,,,--- & 0.02 \\
\hline & 8 & 47 & 12 & $\dagger$ & $\mathbf{n}$ & $\mathbf{n}$ & $\dagger$ & ** & YF, SMD, 一, 一. & $\equiv 0.02$ \\
\hline & \multicolumn{2}{|c|}{ mean 45} & 8.5 & - & - & - & - & 一 & & 0.02 \\
\hline \multirow{9}{*}{2} & 9 & 42 & 8 & $\dagger$ & $\dagger$ & $\dagger$ & $\dagger$ & $\star \star$ & 一 & 0.16 \\
\hline & 10 & 51 & 10 & t & t† & t十 & $\dagger$ & $\star \star$ & $\mathbf{Y F}$ & 0.12 \\
\hline & 11 & 49 & 11 & $\dagger$ & $\dagger$ & $\dagger$ & $\dagger$ & * & YF, SMD & 0.13 \\
\hline & 12 & 43 & 12 & $\dagger$ & H & $\dagger$ & $\dagger$ & $\star \star$ & YF & 0.11 \\
\hline & 13 & 37 & 13 & $\dagger$ & t† & $\dagger$ & $\dagger$ & $\star \star \star$ & YF & 0.13 \\
\hline & 14 & 50 & 14 & $\dagger$ & $\dagger$ & $\dagger$ & $\mathbf{n}$ & * & YF, SMD & 0.12 \\
\hline & 15 & 55 & 14 & $\dagger$ & $\dagger$ & $\dagger$ & $\mathbf{n}$ & * & YF & 0.10 \\
\hline & 16 & 55 & $>25$ & - & - & - & - & 0 & YF & 0.17 \\
\hline & me & an 48 & 13.4 & - & - & - & - & - & & 0.13 \\
\hline
\end{tabular}

1 Weight of the pigs at the end of the feeding period.

2 Observations on the faecal appearance the first day the pigs had diarrhoea are noted in column 1, the same observations on the next 3 days are noted in columns 2,3 and 4 , respectively.

Grading of the faecal appearance:

$$
\begin{aligned}
n: & \text { normal } \\
\dagger: & \text { soft } \\
\dagger \dagger: & \text { watery } \\
\dagger \dagger \dagger: & \text { watery and bloody }
\end{aligned}
$$

3 Grading of the lesions in the mucosa of the spiral colon:

$\because \quad$ A catarrhal inflammation.

* : Few pseudomembranes in the first half.

***: Numerous small pseudomembranes in the first half.

***: Diffuse pseudomembranes in the first half and many small pseudomembranes in the second half.

$\star \star \star \star \star$ : Diffuse pseudomembranes in all parts.

4 YF: yellow fat disease. HD: hepatosis dietetica. SMD: skeletal muscle degeneration and MD: myocardial degeneration.

5 D: died, pig No. 6 was found dead 3 days after the onset of the diarrhoea, the necropsy findings included pronounced hepatosis dietetica. 
cultivation the spirochaete was demonstrated in only 1 of the pigs (No. 9).

Salmonella spp. or other pathogenic enterobacteria were not isolated from any of the pigs.

\section{DISCUSSION}

In the present experiment it is demonstrated that oral inoculation with minced colon from cases of swine dysentery results in both clinical signs and patho-morphological changes accepted as typical for this disease (Harris \& Glock 1972). As a large spirochaete was readily observed in colonic samples from the same pigs, the diagnosis of swine dysentery can definitely be established (Harris 1974). Our observations indicate, however, that the pigs in the 2 groups reacted rather differently to the inoculation, as the incubation time was shorter in Group 1 than in Group 2, and the clinical signs were also considerably more pronounced in the pigs of Group 1 as the animals had a bloody, stained stool before killing. They also developed an unhealthy appearance and reduced appetite during the course of the illness, whereas the diarrhoea in Group 2 was mild and seemed to decline, and the pigs looked otherwise healthy. The clinical difference between Group 1 and 2 was also in good agreement with the patho-morphological lesions observed.

Animals in both groups were fed a basic ration, which, according to other investigations (Van Vleet et al. 1970, Trapp et al. 1970), had an insufficient content of vitamin $E$ and selenium. The feeding procedure, which in Group 2 included a daily supply of the 2 deficient factors, resulted in both higher liver selenium and plasma $\alpha$-tocopherol in this group than in Group 1. The necropsy findings also indicated a higher degree of vitamin $E$ and selenium deficiency in Group 1 than in Group 2, as the patho-morphological lesions considered as typical for deficiency of these factors (Nafstad \& Tollersrud 1970, Jenkins \& Hidiroglou 1972) were much more pronounced in the pigs of Group 1.

A preliminary investigation indicated that treatment with vitamin $E$ reduced the susceptibility to oral exposure of colonic material from cases of swine dysentery (unpublished observations). The observations in the present experiment indicate that a mixed supply of vitamin $E$ and selenium has a similar effect. An influence of selenium on the course of enteritis has occasional- 
ly been mentioned in the literature. Andrews et al. (1968) thus reported the occurrence of profuse diarrhoea in cows with selenium deficiency. It was further shown that administration of selenium could prevent and cure the diarrhoea (Jolly 1960). Oksanen (1965) observed that diarrhoea was a common clinical sign in all age groups of cattle with nutritional muscular degeneration and that inflammatory changes were present in the digestive tract on post-mortem examination of these animals.

An influence of vitamin $E$ on enteritic disorders does not seem to have been investigated, but a positive effect of supplementation with vitamin $\mathbf{E}$ has recently been observed on certain infectious disorders outside the alimentary tract. Tvedten et al. (1973) thus showed that rats supplemented with both vitamins $\mathrm{E}$ and $\mathrm{A}$ were more resistant than rats given rations deficient in either one or both vitamins. In small experimental animals, both vitamin $\mathbf{E}$ and selenium administrations have been shown to increase the immune response (Tengerdy et al. 1972, 1973, Spallholz et al. 1973). Heinzerling et al. (1974) showed that vitamin $E$ caused an increased protection against an Escherichia coli infection in chickens, and that this effect had, at least in part, an immunological background. In pigs, Ellis \& Vorhies (1976) found that vitamin $E$ supply gave an increased serologic response to an E. coli bacterin.

Immunological factors are probably also involved in swine dysentery (Olson 1974, Glock et al. 1976, Schwartz \& Glock 1976). Seen in connection with the above information, it seems possible that there may have been a difference in the immune response between the pigs in the 2 groups in this experiment. This assumption seems to be supported by the observation that a more moderate anaphylactic reaction was provoked in pigs fed a vitamin $\mathrm{E}$ deficient ration than in pigs given feed supplemented with vitamin E (Teige \& Nordstoga 1977). Microbes other than T. hyodysenteriae may, however, also be involved in the development of swine dysentery (Hamdy \& Glenn 1974, Griffin et al. 1976, Alexander et al. 1976) and the participation of such microbes may also have been influenced by immunological factors.

Other possible effects of selenium and vitamin $\mathbf{E}$ deficiency which may have played a pathogenetic role in this experiment will be discussed in subsequent reports. 


\section{REFERENCES}

Alexander, T. J. L., P. D. Wellstead \& M. J. Hudson: Studies of bacteria other than Treponema hyodysenteriae which may contribute to the lesion of swine dysentery. Congr. Int. Pig vet. Soc. 1976, Proc. Sect. L 1.

Andrews, E. D., W. J. Hartley \& A. B. Grant: Selenium-responsive diseases of animals in New Zealand. N. Z. vet. J. 1968, 16, 3-17.

Doyle, L. P.: A Vibrio associated with swine dysentery. Amer. J. vet. Res. 1944, 5, 3-5.

Ellis, R. P.\& M. W. Vorhies: Effect of supplemental dietary vitamin E on the serologic response of swine to an Escherichia coli bacterin. J. Amer. vet. med. Ass. 1976, 168, 231-232.

Eriksen, L. \& S. Andersen. Unders $\varnothing$ gelser over eksperimentelt fremkaldt svinedysenteri. (Experimental swine dysentery). Nord. Vet.-Med. 1970, 22, 161-173.

Espinasse, J.: Étiologie, pathogénie et thérapeutique de l'entérite hémorragique du porc. (Etiology, pathogeny and treatment of hemorrhagic enteritis in the pig). Rec. Méd. vét. 1973, 149, 1519-1530.

Glock, R. D.: The current status of swine dysentery. Feedstuffs 1972, 44, No. 34, p. 32 and 34.

Glock, R. D., K. J. Schwartz \& D. L. Harris: Experimental immunization of pigs against Treponema hyodysenteriae. Congr. Int. Pig vet. Soc. 1976, Proc. Sect. L 11.

Griffin, R. M., D. S. Fernie \& R. W. A. Park: Campylobacter (Vibrio) coli - its possible role in the aetiology of swine dysentery. Congr. Int. Pig vet. Soc. 1976, Proc. Sect. L 3.

Hamdy, A. H. \& M. W. Glenn: Transmission of swine dysentery with Treponema hyodysenteriae and Vibrio coli. Amer. J. vet. Res. 1974, 35, 791-797.

Harris, D. L.: Current status of research on swine dysentery. J. Amer. vet. med. Ass. 1974, 164, 809-812.

Harris, D. L. \& R. D. Glock: Swine dysentery. J. Amer. vet. med. Ass. $1972,160,561-565$.

Harris, D. L., R. D. Glock, C. R. Christensen \& J. M. Kinyon: Swine dysentery. I. Inoculation of pigs with Treponema hyodysenteriae (new species) and reproduction of the disease. Vet. Med. $1972,67,61-64$.

Hashim, S. A. \& G. R. Schuttringer: Rapid determination of tocopherol in macro- and microquantities of plasma. Results obtained in various nutrition and metabolic studies. Amer. J. clin. Nutr. 1966, 19, $137-145$.

Heinzerling, R. H., C. F. Nockels, C. L. Quarels \& R. P. Tengerdy: Protection of chicks against $E$. coli infection by dietary supplementation with vitamin E. Proc. Soc. exp. Biol. (N. Y.) 1974, 146, 279-283.

Ihnat, M.: Fluorometric determination of selenium in foods. J. Ass. off. anal. Chem. 1974, 57, 368-378. 
Jenkins, K. J. \& M. Hidiroglou: A review of selenium/vitamin E responsive problems in livestock: A case for selenium as a feed additive in Canada. Canad. J. Anim. Sci. 1972, 52, 591-620.

Jolly, R. D.: A preliminary experiment on the effect of selenium on the growth rate of calves. N. Z. vet. J. $1960,8,13$.

Nafstad, I. \& S. Tollersrud: The vitamin E-deficiency syndrome in pigs. I. Pathological changes. Acta vet. scand. 1970, 11, 452-480.

Nordstoga, $K$.: Fibrinous colitis in swine, a manifestation of Shwartzman reaction? Vet. Rec. $1973,92,698$.

Nordstoga, K., F. Saxegaard \& E. Johannessen: Fibrin $\varnothing$ s colitt hos gris. (Fibrinous colitis in swine). Nord. Vet.-Med. 1968, 20, 487-494.

Oksanen, $H$. E.: Studies on nutritional muscular degeneration (NMD) in ruminants. Acta vet. scand. 1965, 6, Suppl. 2.

Olson, L. D.: Clinical and pathological observations on the experimental passage of swine dysentery. Canad. J. comp. Med. 1974, 38, 7-13.

Schwartz, K. \& R. D. Glock: Resistance to Treponema hyodysenteriae in passively immunized pigs. Congr. Int. Pig vet. Soc. 1976, Proc. Sect. L 12.

Spallholz, J. E., J. L. Martin, M. L. Gerlach \& R. H. Heinzerling: Immunologic responses of mice fed diets supplemented with selenite selenium. Proc. Soc. exp. Biol. (N. Y.) 1973, 143, 685689.

Teige, J. jr. \& K. Nordstoga: Experimental anaphylaxis in pigs. The influence of the vitamin $E$ content in the feed. Acta vet. scand. 1977, 18, 210-220.

Teige, J. jr., K. Nordstoga, M. Fjфlstad \& I. Nafstad: The generalized Shwartzman reaction in pigs induced by diet and single injection of disintegrated cells or partially purified endotoxin from Escherichia coli. Acta vet. scand. 1973, 14, 92-106.

Tengerdy, R. P., R. H. Heinzerling \& C. F. Nockels: Effect of vitamin $E$ on the immune response of hypoxic and normal chickens. Infect. Immun. 1972, 5, 987-989.

Tengerdy, R. P., R. H. Heinzerling, G. L. Brown \& M. M. Mathias: Enhancement of the humoral immune response by vitamin $E$. Int. Arch. Allergy 1973, 44, 221-232.

Trapp, A. L., K. K. Keahey, D. L. Whitenack \& C. K. Whitehair: Vitamin E-selenium deficiency in swine: differential diagnosis and nature of field problem. J. Amer. vet. med. Ass. 1970, 157, 289300.

Tvedten, H. W., C. K. Whitehair \& R. F. Langham: Influence of vitamins $A$ and $E$ on gnotobiotic and conventionally maintained rats exposed to Mycoplasma pulmonis. J. Amer. vet. med. Ass. 1973, 163, 605-612.

Van Vleet, J. F., W. Carlton \& H. J. Olander: Hepatosis dietetica and Mulberry heart disease associated with selenium deficiency in Indiana swine. J. Amer. vet. med. Ass. 1970, 157, 1208-1219.

Whiting, R. A., L. P. Doyle \& R. S. Spray: Swine dysentery. Purdue Univ. agric. exp. Sta. Bull. 1921, 257, 1-15. 


\section{SAMMENDRAG}

Diettens innflytelse ved eksperimentell svinedysentery. 1. Betydningen av en vitamin $E$ - og selen-fattig diett med tilskudd av $6.8 \%$ tran.

Seksten griser fikk et vitamin E- og selen-fattig fôr, hvorav den ene halvparten (gruppe 2) fikk et daglig tilskudd av de to manglende næringsfaktorene. Etter at grisene hadde blitt fôret med disse diettene i 53 dager, ble de podet med oppmalt colon fra tilfelle av svinedysenteri. Denne podning resulterte i utbrudd av svinedysenteri i begge grupper. Imidlertid var inkubasjonstiden kortere og de kliniske symptomer mer uttalte i gruppe 1 enn i gruppe 2. De patologiske forandringer varierte også mellom gruppene. Hos grisene i gruppe 1 ble tydelige pseudomembran $\varnothing$ se forandringer sett $\mathrm{i}$ colonspiralen. I gruppe 2 fantes hovedsakelig en katarrhalsk betennelsestilstand; pseudomembraner såes bare $i$ en avgrenset del av colon hos 4 av grisene. Både de analysene som er utf $\varnothing$ rt og de patologiske forandringer som er funnet indikerer en bedre vitamin $E$ og selen status hos grisene i gruppe 2. Det blir derfor konkludert med at tilskuddet av vitamin $\mathrm{E}$ og selen i stor grad $\varnothing$ kte motstandskraften overfor svinedysenteri.

(Received May 4, 1977).

Reprints may be requested from: K. Nordstoga, the Department of Pathology, Veterinary College of Norway, P. O. Box 8146, Oslo Dep., Oslo 1, Norway. 